\title{
ДІЯЛЬНІСНО-ПРАКТИЧНИЙ КОМПОНЕНТ У СТРУКТУРІ ПРОФЕСІЙНО- ОСОБИСТІСНОГО ДОСВІДУ МАЙБУТНЬОГО ВЧИТЕЛЯ МУЗИКИ
}

Попович Н. М. Діяльнісно-практичний компонент у структурі професійно-особистісного досвіду майбутнього вчителя музики.

У статті проаналізовано сутність діяльнісно-практичного компонента у структурі професійноособистісного досвіду майбутнього вчителя музики. Обгрунтовано зміст практичної підготовки студентів в умовах вищого навчального закладу.

Ключові слова: діяльнісно-практичний компонент, професійно-особистісний довід, учитель музики, практична підготовка студентів.

Попович Н. М. Деятельностно-практический компонент в структуре профессиональноличностного опыта будущего учителя музыки.

В статье проанализирована сущность деятельностно-практического компонента в структуре профессионально-личностного опыта будущего учителя музыки. Обоснована роль практической подготовки студентов в условиях высшего учебного заведения.

Ключевые слова: деятельностно-практический компонент, профессионально-личностный опыт, учитель музыки, практическая подготовка студентов.

Popovich N. M. Activity-practical component in the structure of professional and personal experience of future music teachers.

In article the essence of an is active-practical component in structure of is professional-personal experience of the future teacher of music is analysed. The role of practical preparation of students in the conditions of a higher educational institution is proved.

Key words: active-practical component, professional-personal experience, teacher of music, practical preparation.

У період оновлення всіх аспектів життєдіяльності суспільства та розширення міжнародних зв'язків рівень фахової підготовки майбутнього вчителя музики в системі неперервної освіти визначається сформованістю його особистісних якостей та професійних умінь, серед яких особливе місце належить професійно-особистісному досвіду.

Необхідно підкреслити, що дослідження, де 6 із позицій системного підходу розглядалися теоретичні та практичні аспекти проблеми формування професійноособистісного досвіду студентів мистецьких спеціальностей, відсутні. Зазвичай дослідники віддають перевагу формуванню окремих складників досвіду майбутнього фахівця в системі неперервної педагогічної освіти.

Так, дослідженню проблем професійної підготовки фахівців у системі неперервної професійної освіти присвячено праці С. Гончаренка, І. Зязюна, В. Кременя, Н. Ничкало та ін.; теоретико-методологічні засади підготовки майбутніх фахівців висвітлювали В. Бондар, Н. Кузьміна, В. Сластьонін та ін.; особливості розвитку творчої особистості майбутніх учителів музики у процесі професійної підготовки розглядали Н. Гузій, О. Олексюк, О. Отич, О. Рудницька, С. Сисоєва, О. Щолокова та ін.; взаємодія теоретичної і практичної підготовки студентів вищих педагогічних навчальних закладів розглядається в дослідженнях О. Абдуліна, А. Бойко, А. Бондар, В. Краєвського, А. Петрова та ін.

Mema cmammi - проаналізувати сутність діяльнісно-практичного компонента у структурі професійно-особистісного досвіду майбутнього вчителя музики.

Важливими складниками процесу підготовки майбутніх фахівців музичнопедагогічного профілю $є$ діяльнісний і практичний компоненти. Настанова на взаємодію цих складників передбачає орієнтацію на здобуття майбутніми вчителями музики знань та 
практичного досвіду, пов'язаного із музично-творчою та професійно-педагогічною діяльністю; навичок свідомого володіння як процесом власного професійного становлення, так і музично-творчого розвитку своїх майбутніх учнів; умінь не лише обирати і застосовувати потрібні методи, прийоми і способи удосконалення власної майстерності, а й користуватися ними в процесі професійної діяльності.

Аналіз специфіки діяльнісно-практичного компонента у структурі професійноособистісного досвіду необхідно, на нашу думку, здійснювати в руслі діяльнісного підходу.

У вітчизняній науковій традиції категорія діяльності загалом розглядалася як онтологічна основа концепції людини, сутність якої пов'язувалася із здатністю до створення принципово нових можливостей для власного розвитку. Сутнісні сили людини за таких умов $\epsilon$ універсально-діяльнісними здібностями, наповненими конкретноісторичним змістом.

У контексті діяльнісного підходу значна увага науковців приділялася дослідженням продуктивності педагогічної діяльності і майстерності, успішно напрацьовувалися схеми, моделі, критерії професіоналізму педагогічної діяльності, що відображають уявлення про вчителя-професіонала.

Діяльнісний підхід грунтується на визнанні діяльності основою, засобом і вирішальною умовою формування досвіду майбутнього фахівця. Цей факт зумовлює необхідність реалізації в педагогічному дослідженні і практиці діяльнісного підходу, що тісно пов'язаний із особистісним.

Діяльнісний підхід вимагає спеціальних зусиль, спрямованих на активізацію та варіативність дій студента, що передбачає вироблення вмінь визначати мету і завдання професійної діяльності, планувати діяльність, організовувати, виконувати, регулювати, контролювати іï, аналізувати й оцінювати іiі результати.

Практична діяльність як стрижневий аспект досвіду майбутнього фахівця набуває видової своєрідності в різноманітних сферах реалізації активності особистості, у зв'язку з чим виникає проблема розкриття специфіки конкретного вияву діяльнісної активності, зокрема музично-навчальної, професійної, педагогічної, мистецької діяльності тощо.

Науковці А. Брушлинський, О. Леонтьєв, С. Рубінштейн [3; 6; 7], досліджуючи специфіку діяльнісного підходу, наголошують, що основними його принципами $є:$

- принципи розвитку, історизму, предметності;

- принцип активності, що включає активність надситуативну як специфічну особливість людської психіки;

- принцип інтеріоризації-екстеріоризації як механізмів засвоєння суспільноісторичного досвіду;

- принцип єдності будови зовнішньої й внутрішньої діяльності;

- принцип системного аналізу.

У принципі розвитку об'єктивно виявляються й реалізуються детермінація поведінки, зв'язок психіки та діяльності. За цим принципом кожному рівню детермінації притаманний свій тип розвитку. На рівні організму суб'єкт розвивається в процесі визрівання і формування психофізіологічних підструктур, на рівні індивіду - у процесі діяльності присвоєння, а на рівні особистості - у процесі перетворювальної діяльності.

Принцип історизму вимагає розглядати дійсність з позиції іiі змін у часі.

Зазначені принципи відображають у своєму змісті фундаментальні закономірності навчання (усталені залежності його результатів від умов організації), які об'єктивно існують у реальному педагогічному процесі.

Підвищення якості професійно-практичної підготовки майбутнього вчителя музики забезпечується використанням в умовах вищої школи таких принципів навчання, як: неперервності педагогічної освіти, ії демократизації, орієнтації на творчу діяльність і неповторність особистості кожного фахівця, забезпечення диференційованого й індивідуально-творчого підходу до його формування. 
Педагогічне керівництво процесом формування діяльнісно-практичного компонента у структурі професійно-особистісного досвіду майбутніх фахівців передбачає створення оптимальних умов для активної позиції суб'єкта діяльності, завдяки чому відбуватиметься свідоме й грунтовне набуття ним певного досвіду.

А. Вербицький зазначає, що діяльнісна теорія набуття досвіду є найбільш розвиненою та такою, що відповідає потребам перебудови освітніх процесів [4, с. 48]. Розробляючи на iї основі знаково-контекстне навчання, він виокремлює такі суперечності між навчальною діяльністю та професійною під час традиційної підготовки, на подолання яких має бути спрямоване оновлення системи підготовки майбутніх фахівців:

- суперечність між абстрактним предметом навчальної діяльності (тексти, знакові системи, програми дій) і реальним предметом майбутньої діяльності, у якому знання не подано в «чистому вигляді», а задані в загальному контексті педагогічних процесів та ситуацій. Традиційне навчання не забезпечує достатньо ефективних засобів та умов для розв'язання цієї суперечності, що породжує відомі феномени формальних знань, неможливість застосування їх на практиці, труднощі інтелектуальної та соціальної адаптації випускників до умов праці;

- суперечність між системним використанням знань у регуляції професійної діяльності і «розпорошенням» їх засвоєння на заняттях з різних навчальних дисциплін. Реальна можливість систематизації отриманої у ВНЗ «мозаїки» знань з'являється лише після його закінчення, у самостійній роботі молодого фахівця. Засвоєння знань «про запас» та несистемно зовсім не сприяє розвитку інтересу студента як до самих знань, так і до майбутньої професійної діяльності;

- суперечність між індивідуальним способом засвоєння знань та досвіду в навчанні, індивідуальним характером навчальної роботи студентів і колективним характером професійної праці, що передбачає обмін іï продуктами, міжособистісну взаємодію фахівців тощо;

- суперечність між залученням до процесу професійної діяльності особистості фахівця на рівні творчого мислення та соціальною активністю й опорою традиційного навчання насамперед на процеси уваги, сприйняття, пам'яті, руху. Розв'язання цієї суперечності пов'язане зі створенням ситуацій, адекватних професійній діяльності, що дозволяють залучати студентів до педагогічного процесу цілісно, створювати умови для професійноособистісного самовизначення, прийняття ефективних рішень;

- суперечність між так званою «відповідаючою» позицією студента, яку передбачає традиційний підхід у навчанні (мета визначається викладачем, студент відповідає на його питання, виконує навчальні завдання, є активним за особистою вказівкою чи дозволом) $\mathrm{i}$ принципово іншою - ініціативною в предметному та творчому аспекті позицією фахівця, якому потрібно приймати рішення, висувати ідеї, розробляти нові технології тощо;

- суперечність між відношенням змісту навчальної діяльності до «минулого» досвіду, опредмеченого у знакових системах, та орієнтацією суб'єкта навчання на майбутній зміст професійної діяльності. Майбутнє постає для суб'єкта як абстрактна перспектива застосування знань, що не може бути достатнім мотивуючим чинником навчання;

- суперечність між формами організації навчально-пізнавальної діяльності студентів і формами професійної діяльності фахівців у той час, як за діяльнісної теорії засвоєння вони повинні бути адекватними, якщо основною метою є опанування діяльністю.

Діяльнісний і практичний підходи вчителя до процесу навчання музики і музичного виховання, розроблення, запровадження нових методик, прийомів, оптимальне їх поєднання, сприяють створенню принципово нових систем навчання, виховання й музично-творчого розвитку школярів.

У свою чергу, одним 3 вагомих чинників, що забезпечуватиме ефективність формування діяльнісно-практичного компонента досвіду майбутнього вчителя музики, $\epsilon$ професійно-творча активність, яка постає умовою й результатом музично-педагогічної діяльності, забезпечує нестандартний підхід і творче розв’язання професійних завдань. 
Змістовний аспект творчої активності як інтегративне особистісно-діяльнісне утворення поєднує в собі інтереси і потреби, спрямованість і схильності, рівень розвитку інтелектуальних, емоційних, вольових якостей і дії, що зумовлюють результативність різних видів діяльності студентів.

Визначення змісту творчої активності як найважливішої риси професіоналізму сучасного вчителя музики передбачає врахування особливостей студентського віку i структурних компонентів особистості студента.

Науковці С. Архангельський, Л. Буєва, Т. Шамова та ін. наголошують, що активність характеризується як міра діяльнісного вираження суспільної сутності фахівця, як кількісно-якісний аспект його професійної діяльності і як система впливу людини на різні сфери життя. На їхню думку, професійна підготовка у вищій школі повинна бути спрямована на формування цього складного особистісного утворення як показника вчительського професіоналізму.

Творча активність виявляється тоді, коли особистість із властивим їй відповідним мисленням має ще сформувати внутрішню мотивацію до діяльності, вміє застосовувати прийоми творчого мислення до розв'язування конкретних педагогічно-творчих завдань.

Для активізації діяльності студентів велике значення має використання в музичнопедагогічній практиці активного діалогу, ділової гри, аналізу проблемних ситуацій, навчальних досліджень, спеціальних творчих вправ тощо.

Сутність активності, на наш погляд, необхідно розглядати з урахуванням специфіки студентського віку й навчального процесу вищої школи. Адже творча активність $є$ своєрідним прагненням студента проникнути в сутність досліджуваних речей, явищ, прагненням до застосування нових прийомів подолання труднощів, здатність вносити елементи новизни в способи виконання навчального завдання, розв'язання професійнотворчих завдань.

Рушійною силою діяльнісно-творчого процесу $є$ потреба у творчості, заснована на усвідомленні невідповідності засвоєних алгоритмів, індивідуально-стильових особливостей особистості тієї конкретної ситуації, що складається під час виконання нею професійних функцій. У ситуаціях, які вимагають імпровізації, нестандартного розв'язання завдань, відбувається інтеграція психічних властивостей особистості й водночас закріплення деяких ऑї стійких виявів, які стимулюють творчу активність у практичній діяльності.

Зміст професійно-творчої активності як складного особистісного утворення формується всіма сферами внутрішнього світу особистості: інтелектуальною, емоційною, вольовою, навичками, звичками, здібностями.

Професійно-творча активність виражається в діалектичній єдності та сполученні ініціативи 3 відповідальністю, ретельністю, організованістю, чіткістю діяльності, самостійності - 3 дисципліною, продуктивної сторони діяльності - 3 репродуктивною, творчості - 3 нормативністю та традиціями (О. Білоус).

На всіх освітньо-кваліфікаційних рівнях у структурі підготовки майбутнього вчителя музики передбачена педагогічна практика, від змісту, форм і методів якої значною мірою залежить ефективність формування діяльнісно-практичного компонента досвіду студентів та їх подальша адаптація до професійної діяльності.

Практична діяльність в умовах вищого навчального закладу, 3 одного боку, $\epsilon$ перевіркою професійних якостей майбутнього вчителя, з іншого, - найважливішим етапом формування педагогічних здібностей, вияву їх у самостійній педагогічній діяльності. Водночас студент виконує різні функціональні ролі: організатора навчально-виховної діяльності тих, хто навчається, та організатора власної діяльності, зміст якої $є$ для нього особливим предметом усвідомлення, аналізу та оцінки.

Процес підготовки студентів до проведення занять є складним і відповідальним, оскільки така діяльність потребує максимальної концентрації зусиль і вияву сформованого рівня педагогічної майстерності. 
Цей процес вимагає тривалого часу і передбачає не тільки написання конспекту заняття, а й психологічну підготовку до його проведення, глибоке осмислення мети заняття, зміст основних етапів і положень, власне творче бачення дисципліни, усвідомлення іiі значущості, впевненості у своїх знаннях; оволодіння майстерністю виступу й діалогічною взаємодією з аудиторією.

Слід підкреслити, що від якості організації практичної діяльності студентів залежить реалізація основного завдання в тенденції модернізації освіти - активізувати мотивацію діяльності в ході вивчення навчальних дисциплін, формувати в майбутніх фахівців самостійне, креативне й професійне мислення, динамізувати потребу у творчій педагогічній діяльності, забезпечуючи цим самим високий рівень сформованості професійно-особистісного досвіду.

Отже, діяльнісно-практичний компонент професійно-особистісного досвіду, як і процес його формування в майбутніх учителів музики, слід розглядати як досить специфічну i складноструктуровану систему, що охоплює різноманітні елементи та їх функціональні взаємозв'язки, які вимагають обгрунтованого визначення і теоретичного моделювання, а також віднаходження системоутворювальних чинників для педагогічного управління процесами його формування та розвитку.

\section{Література}

1. Архангельский С. И. Учебный процесс в высшей школе, его закономерные основы и методы / С. И. Архангельский. - М. : Высшая школа, 1980. - 384 с. 2. Білоус О. С. Формування творчої активності студентів у процесі навчання предметам музичного циклу / О. С. Білоус // Науковий часопис Національного педагогічного університету імені М. П. Драгоманова. - Серія 16: Творча особистість учителя: проблеми теорії і практики: [зб. наук. праць] / ред. кол.: О. Г. Мороз, Н. В. Гузій. - Вип. 2 (12). - К. : НПУ, 2004. - С. 59-62. 3. Брушлинский А. В. Субъект: мышление, учение, воображение: Избранные психологические труды. - М. : Ин-т практической психологии, 1996. - 390 с. 4. Вербицкий А. А. Активное обучение в высшей школе: контекстный подход / А. А. Вербицкий. М.: Высшая школа, 1991. - 206 с. 5. Выготский Л. С. Педагогическая психология. - М. : ПедагогикаПресс, 1996. - 536 с. 6. Леонтьев А. Н. Избранные психологические произведения: В 2-х т. / под ред. В. В. Давыдова. - Т. 2. - М. : Педагогика, 1983. - 318 с. 7. Рубинштейн С. Л. Основы общей психологии: В 2 т. Т.2 - М. : Педагогика, 1989. - 324 с.

УДК $371.132+371.134: 373.3$

I. В. Размолодчикова, кандидат пед. наук, ст. викладач, Криворізький педагогічний інститут ДВНЗ «Криворізький національний університет»

\section{ВПЛИВ ЦІННССИХ ОРІЄНТАЦІЙ НА ФОРМУВАННЯ ІМІДЖУ МАЙБУТНЬОГО ВЧИТЕЛЯ}

Размолодчикова I. В. Вплив ціннісних орієнтацій на формування іміджу майбутнього вчителя.

У статті здійснено спробу проаналізувати вплив ціннісних орієнтацій на формування та розвиток особистості сучасного вчителя початкових класів.

Ключові слова: учитель, саморозвиток, ціннісні орієнтації, професійно-педагогічні цінності, культура, самовдосконалення.

Размолодчикова И. В. Влияние ценностных ориентаций на формирование имиджа будущего учителя.

В статье проанализировано влияние ценностных ориентаций на формирование и развитие личности современного учителя начальных классов.

Ключевые слова: учитель, саморазвитие, ценностные ориентации, профессиональнопедагогические ценности, культура, самосовершенствование.

Razmolodchikova I. V. The influence of value orientations to formation of image of future teacher. 